\title{
Low temperature exerts protective effects by inhibiting mitochondria-mediated apoptosis pathway following pressure injury to rat muscle
}

\author{
A baixa temperatura exerce efeitos protetores ao inibir a via de apoptose \\ mediada por mitocôndrias após lesão por pressão no músculo de rato \\ La baja temperatura ejerce efectos protectores al inhibir la vía de apoptosis mediada \\ por mitocondrias después de una lesión por presión en el músculo de la rata
}

How to cite this article:

Zhang W, Miao R, Tang J, Su O, Li P, Pi H. Low Temperature Exerts Protective Effects by Inhibiting Mitochondria-mediated Apoptosis Pathway Following Pressure Injury to Rat Muscle. Rev Esc Enferm USP. 2021;55:e20200319. DOI: https://doi.org/10.1590/1980-220X-REEUSP-2020-0319.

\author{
D Wenyu Zhang ${ }^{1,2,3}$ \\ iD Ran Miao \\ Jingping Tang ${ }^{2}$ \\ Qingqing $\mathrm{Su}^{2}$ \\ Peifeng $\mathrm{Li}^{5}$ \\ Hongying $\mathrm{Pi}^{2}$
}

Wenyu Zhang, Ran Miao and Jingping Tang contributed equally to this work

${ }^{1}$ Capital Medical University School of Nursing, Beijing, China.

${ }^{2}$ Medical School of Chinese PLA, Beijing, China.

${ }^{3}$ College of Social Administration, Department of Senior Citizens Welfare, Beijing, China.

${ }^{4}$ Capital Medical University, Beijing Chao-Yang Hospital, Medical Research Center, Beijing, 100853, China.

${ }^{5}$ Institute for Translational Medicine,

Qingdao University, Qingdao, China.

\begin{abstract}
Objective: We aimed to determine the effect of different low-temperature range interventions at different time-points in a rat model of pressure injury (PI) produced by Ischemia/Reperfusion (I/R) injury. Methods: Sprague-Dawley rats were randomly assigned to blank control, injury control, and temperature intervention groups. Rats in the injury control and temperature intervention groups (involving exposure to different temperature range at different time-points) were subjected to three cycles of I/R injury with $2-\mathrm{h}$ ischemia and $0.5-\mathrm{h}$ reperfusion to induce PI. Results: The muscle tissues exhibited degenerative changes after compression. Low temperature intervention of $16-18^{\circ} \mathrm{C}$ in the ischemia period resulted in the lowest degree of tissue damage and significantly decreased levels of $\mathrm{Bcl}-2$-associated $\mathrm{X}$ protein (Bax), caspase- 9 , and caspase-3. Moreover, it resulted in the highest expression level of B-cell lymphoma 2 (Bcl-2) and lowest expression levels of Bax, caspase- 9 , and caspase- 3 in muscle tissues among all intervention groups. Conclusion: Low-temperature intervention at $16-18^{\circ} \mathrm{C}$ during the ischemia period showed optimal effects on the expressions of apoptotic factors during the development of PI with I/R-induced tissue damage.
\end{abstract}

\section{DESCRIPTORS}

Pressure Ulcer; Apoptosis; Temperature; Ischemia/Reperfusion; Mitochondria. 


\section{INTRODUCTION}

Pressure Injury (PI) is characterized by localized damage to skin and/or underlying soft tissues caused by intense and/or prolonged pressure or pressure in combination with shear, usually leading to many serious complications ${ }^{(1)}$. Microclimate, nutritional status, local perfusion, and condition of the soft tissue were also found to influence PI. During nursing care, regular turning over of patients is the main method for ameliorating $\mathrm{PI}^{(2)}$. Previous studies have shown that PI can be prevented in 50\% of cases, which implies that this injury is difficult to prevent in half of all cases $^{(3)}$. Therefore, development of effective interventions to prevent its occurrence is a key imperative.

The effect of low temperature on the formation of PI has recently garnered interest. Decreasing the skin temperature was shown to reduce the degree of pressure-induced tissue damage ${ }^{(4)}$. Local cooling while applying pressure had the same effect as decreasing pressure in healthy young patients ${ }^{(5)}$. Although studies have shown that low temperature can help prevent PI, the precise range of temperature intervention and the intervention time-points are still unclear. There is a paucity of studies that have investigated these aspects.

Recent studies have shown that Ischemia/Reperfusion (I/R injury) is the major contributing factor in the development of $\mathrm{PI}^{(6)}$. Ischemia results from deficient blood supply to tissues, which lead to cell hypoxia and disruption of cellular metabolism. Reperfusion refers to the restoration of blood flow following tissue injury that results from the buildup of metabolic by-products ${ }^{(7)}$. I/R injury of soft tissue leading to $\mathrm{PI}$ is a major complication in many clinical $\operatorname{scenarios}^{(8)}$. Previous studies have shown that PI is caused by a complex cascade of inflammatory mediators and that the cell death process is modulated by a series of mediators ${ }^{(9)}$. Muscle is the most common site for formation of pressure ulcers, which is most likely mediated by apoptosis according to multiple reports ${ }^{(10)}$.

Mitochondria-mediated apoptosis plays an important role in muscle damage caused by stress injury. Mitochondrial hemostasis is critical for the maintenance of the normal function of cells. After being stimulated by endogenous factors, the factor Bax accumulates on the mitochondrial membrane, which leads to change of mitochondria membrane potential and permeability. Increased release of cytochrome c (cyt-c) from mitochondria into the cytoplasm activates Caspase-9, forming an apoptotic body complex that induces the activation of caspase- 3 ; this results in a cascade reaction eventually leading to apoptosis and cell death ${ }^{(11)}$. After injury, a series of apoptotic proteins released from muscle cells accumulate at the injury site. bcl-2/bax ratio is a marker of apoptotic activity as upregulation of bax is important for activation of apoptosis. Recent studies have demonstrated activation of apoptotic pathways during the development of I/R injury ${ }^{(12-14)}$. In other studies, apoptosis inhibitors were shown to alleviate muscle injury induced by mechanical compression ${ }^{(15-16)}$. Therefore, the main objective of this study was to determine and explain the effect of low temperature intervention in a rat model of PI. Another aim was to discover the most suitable temperature range and the suitable time-point for intervention to prevent PI. Further, we discuss the mechanism of action of this type of intervention.

\section{METHODS}

\section{Study Design}

This was an in vivo experimental study to investigate the effect of low temperature on PI and to clarify the intervention mechanism through the establishment of a PI animal model.

Male Sprague Dawley rats aged 6-8 weeks and weighing 160-200 g were used in this study. Rats were randomly assigned to the following groups: blank control, injury control, $17 \mathrm{I}$ (temperature: $16-18^{\circ} \mathrm{C}$ during ischemia period), $17 \mathrm{R}$ (temperature: $16-18^{\circ} \mathrm{C}$ during reperfusion period), 22I (temperature: $21-23^{\circ} \mathrm{C}$ during ischemia period), $22 \mathrm{R}$ (temperature: $21-23^{\circ} \mathrm{C}$ during reperfusion period), 27I (temperature: $26-28^{\circ} \mathrm{C}$ during ischemia period), and $27 \mathrm{R}$ (temperature: $26-28^{\circ} \mathrm{C}$ during reperfusion period). All rats were housed in a facility at the Institute of Translational Medicine at Qingdao Medical University (Qingdao, China).

\section{Pressure Injury Model}

Each rat was administered an intraperitoneal injection of the anesthetic pentobarbital sodium and fixed in a supine position. Sodium pentobarbital powder was dissolved in $1 \%$ pentobarbital sodium $(0.01 \mathrm{~g} / \mathrm{mL})$ injection with normal saline, the method of using anesthetic according to the standard of $30 \mathrm{mg} / \mathrm{kg}^{(17)}$. The anesthesia state of rats was judged by gently squeezing the mouse tail and observing the respiratory rate. Rats lying down still, breathing evenly, and showing no response to squeezing the tail was considered indicative of adequate anesthesia. With the exception of the blank control group, the rats were subjected to three cycles of $I / R$, each of which included a $2-h$ ischemia period and a 0.5 -h reperfusion, resulting in the local soft tissue PI model. A static pressure of $24 \mathrm{kPa}$ was applied to a $5.0-\mathrm{cm}^{2}$ area in the middle region of a randomly selected limb of each rat. The local pressure $(\mathrm{P})$ was calculated according to the equation $P=F / S$, where $F$ is the force (mass $\times$ gravity) and $S$ is the surface area. The compression load was applied using a controlled indenter with a cylindrical structure that had a diameter of $2.52 \mathrm{~cm}$ at the contact point. The compression force exerted on the thigh was continuously monitored and controlled by an electronic balance. The controlled indenter was also connected to a temperature control instrument and a temperature sensor to allow precise control and monitoring of the temperature of the pressure head (Figure 1). All rats in the intervention groups were treated with respective temperatures at the point of contact during compression or reperfusion. Intraperitoneal injections of pentobarbital sodium $(0.1 \mathrm{~mL}, 10 \mathrm{mg} / \mathrm{kg})$ were administered to keep the rats immobile during the experiment, if necessary ${ }^{(18)}$. Rats were routinely reared for $12 \mathrm{~h}$ after successful modeling. Subsequently, all rats were sacrificed by administering 


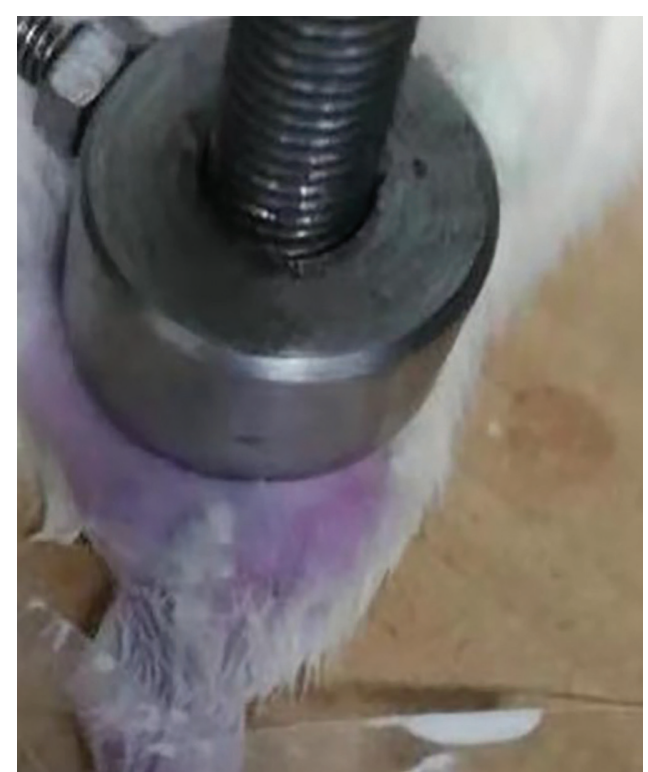

Figure 1 - Ischemia-Reperfusion Pressure Injury in rats - Beijing, China, 2020.

intraperitoneal overdose of pentobarbital sodium $(200 \mathrm{mg} / \mathrm{kg})$. Disappearance of breath and heart-beat, stiffening of bodies, and absence of corneal reflex and tail reflex were used as indicators of animal death. The compressed tissue was dissected, immediately frozen in liquid nitrogen, and stored at $-80^{\circ} \mathrm{C}$ until further analyses.

Animal model of pressure injury is shown in Figure 1.

\section{Data Collection}

Muscle tissues in the compressed region were cut in the direction of the muscle filaments and the histomorphological characteristics of the tissues were observed by hematoxylin and eosin (H\&E) staining. In addition, the protein and mRNA expressions of apoptotic factors were determined using Western blot analysis and quantitative polymerase chain reaction (qPCR), respectively.

\section{Morphological Observations by Light Microscopy}

Immediately after death, each specimen was frozen in liquid nitrogen. Then the tissues were dissected, fixed in $4 \%$ formaldehyde, embedded in paraffin, and sliced into $5-\mu \mathrm{m}$ sections using a microtome. H\&E-stained sections were observed under microscope to estimate and evaluate the pathological status of the compressed muscle tissues. Subsequently, the cellular histological features were observed and photographs of four randomly selected image fields were obtained at 200-fold magnification.

\section{Western Blot Analysis}

A 30- $\mu$ g aliquot of proteins from each muscle tissue sample was re-suspended in sodium dodecyl sulfatepolyacrylamide gel electrophoresis (SDS-PAGE) loading buffer, using $80 \mathrm{~V}$ to run concentrated gel and $120 \mathrm{~V}$ or $140 \mathrm{~V}$ to run separation gel. The PVDF membrane was activated by methanol immersion in advance. Electrophoresis time was 1 hour at $220 \mathrm{~mA}$. The PVDF membrane was transferred into the blocking solution (5\% skim milk) and incubated at room temperature for 1 hour on a shaker, then washed with TBST solution for 5 minutes, and placed in a blocking solution-skim milk (2g skim milk $+20 \mathrm{~mL}$ TBS). After shaking the bed slowly at room temperature for $1 \mathrm{~h}$, the membrane was washed with TBST three times (10 minutes each). The blocked PVDF membrane was incubated overnight with the primary antibody at $4^{\circ} \mathrm{C}$, and washed three times with TBST ( 5 minutes each). Then the membrane was incubated with the secondary antibody for 2 hours at room temperature, and washed with TBST three times (5 minutes each). The proteins were visualized using an Imaging System.

\section{Quantitative Polymerase Chain Reaction}

Total RNA was extracted from the homogenate (phosphate-buffered saline was mixed with muscle tissue to prepare the homogenate) according to the manufacturer's instructions. RNA was extracted with the Script Reverse Transcription System and used to synthesize the cDNA. The cDNA was prepared as a template for the experiments or temporarily stored at $-80^{\circ} \mathrm{C}$. Specific primers for GAPDH (endogenous control), B-cell lymphoma 2 (Bcl-2), caspase-3, caspase-9, and Bcl-2-associated X protein (Bax) genes were designed for $\mathrm{qPCR}$ to detect the relative expression levels. qPCR for Bax, Bcl-2, caspase-3, and caspase-9 was performed using the Bio-Rad Detection System (Bio-Rad, Hercules, CA, USA). The qPCR reaction was carried out using SYBR Premix Ex Taq (Takara, Tokyo, Japan). Data were analyzed using the relative expression level of each gene. The data are shown in Table 1.

\section{Data Analysis}

The data for each treatment group are expressed as mean \pm standard deviation. The F-test was used to compare the expression levels among the treatment groups and the $t$ test was used for comparisons between two groups using Excel 2010. $P$ values $<0.05$ were considered indicative of statistical

Table 1 - Primer sequences - Beijing, China, 2020.

\begin{tabular}{lcc}
\hline & Sequences of primers & Primer sequences \\
\hline Bcl-2 & F: GAGGATTGTGGCCTTCTTTG & R: AGGTACTCAGTCATCCACA \\
Bax & F: ATGGAGCTGCAGAGGATGA & R: CCAGTTTGCTAGCAAAGTAG \\
Caspase-3 & F: AAGCCGAAACTCTTCATC & R: TGAGCATTGACACAATACAC \\
Caspase-9 & F: GGCTGTCTACGGCACAGATGGA & R: CTGGCTCGGGGTTACTGCCAG \\
GAPDH & F: CGGAGTCAACGGATTTGGTCGTAT & R: AGCCTTCTCCATGGTGGTGAAGAC \\
\hline
\end{tabular}


significance. Morphological differences among the groups were observed using color images obtained under optical and electron microscopes at 200-fold magnification.

\section{Ethical Aspects}

All animal experiments were approved by the Animal Ethics Management Committee, Translational Medicine, and the Basic Research and Development of Qingdao Medical University (Number:20190130).

\section{RESULTS}

\section{Tissue Morphology}

The normal muscle fibers had a clear structure. After modeling, there was appearance of degenerative lesions in the muscle tissue. The muscle fibers showed disordered arrangement, widened interstitium, waxy degeneration, twisting, vacuolization, and dissolution and fracture of some muscle fibers. In addition, there was presence of massive inflammatory cells in the interstitial spaces. The $17 \mathrm{I}$ and $17 \mathrm{R}$ groups showed more regular arrangement of muscle fibers than other groups, but still exhibited locally increased gap and infiltration by inflammatory cells in the necrosis area.
The muscle fibers in the 17I group were more regular than those in the $17 \mathrm{R}$ group.

Histological images are shown in Figure 2.

\section{Effects of Low Temperature on Activation of Mitochondria-mediated Apoptosis Pathway in Rats}

We found higher levels of Caspase-3, Bax, and Caspase-9 and low level of $\mathrm{Bcl}-2$ expression in the injury control group compared with the blank group. The expressions of Bax, Caspase- 3 , and Caspase- 9 were highest in the injury control group.

Results of qPCR showing alterations in the mRNA expression levels of apoptosis factors in muscle tissues after injury are shown in Table 2 . We observed a marked decrease in the $\mathrm{Bcl}-2 / \mathrm{Bax}$ ratio in the muscle after injury compared with the blank control group (blank control group: $3.21 \pm$ 0.1 ; injury control group: $0.65 \pm 0.07$ ). A significant change in the $\mathrm{Bcl}-2 / \mathrm{Bax}$ ratio was observed in this temperature range-treated groups compared with other groups (17I: $1.3 \pm 0.1$; $17 \mathrm{R}: 1.05 \pm 0.10 ; 22 \mathrm{I}: 1.26 \pm 0.3$; 22R: $0.87 \pm$ $0.1 ; 27 \mathrm{I}: 0.98 \pm 0.09 ; 27 \mathrm{R}: 0.75 \pm 0.08)$. The expressions of Caspase-3 and Caspase-9 were lowest in 17I group

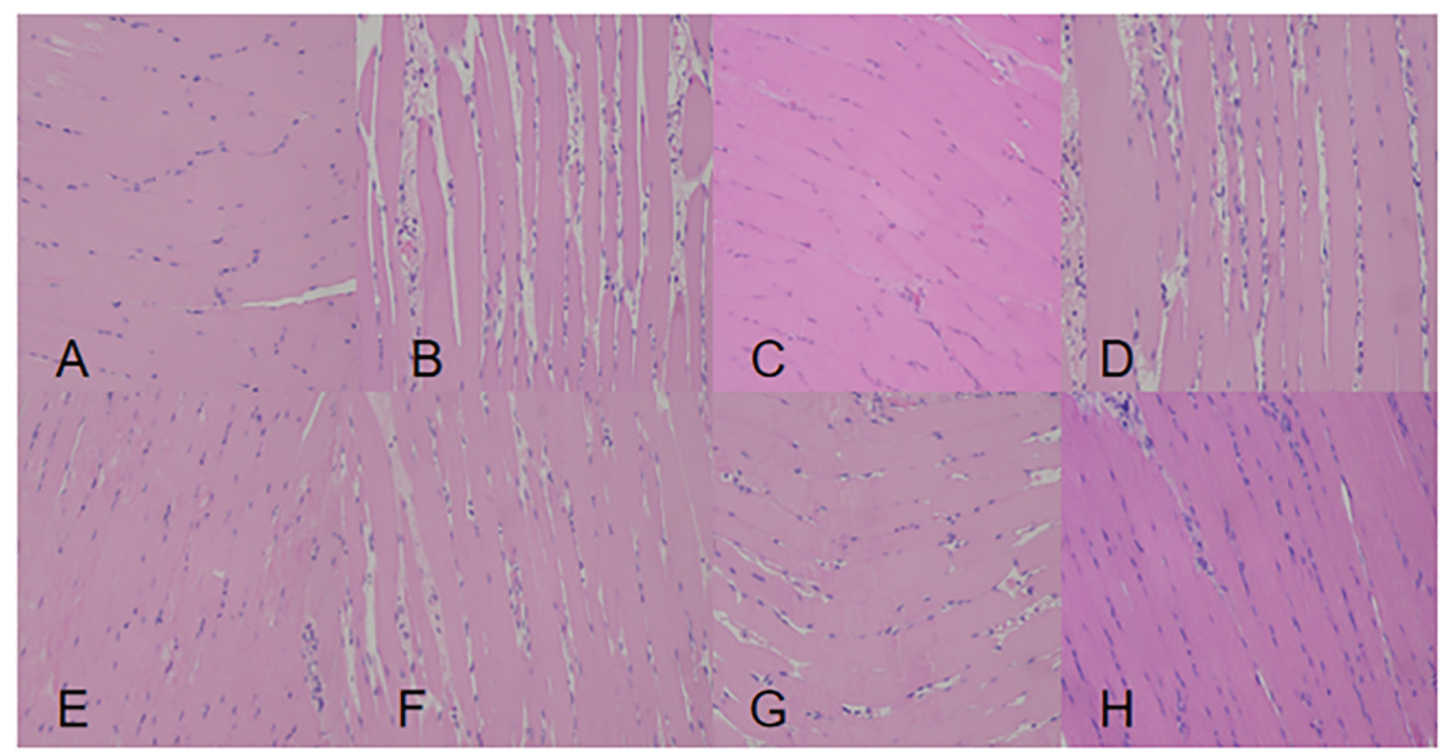

Figure 2 - H\&E-stained sections showing morphology of muscle tissues. Images are obtained at $200 \times$ magnification using an optical microscope (A: normal blank group; B: blank control group; C: 17I; D: 17R; E: 22I; F: 22R; G: 27I; H: 27R) - Beijing, China, 2020.

Table 2 - Expressions of Bcl-2, Bax, Caspase-3, Caspase-9 in various groups - Beijing, China, 2020.

\begin{tabular}{|c|c|c|c|c|c|c|c|c|}
\hline Group & $17 I$ & $17 R$ & $22 I$ & $22 R$ & 271 & $27 R$ & Blank & Injury \\
\hline $\mathrm{Bcl}-2$ & $1.547 \pm 0.119^{* *}$ & $1.283 \pm 0.101^{* *}$ & $1.24 \pm 0.024^{* \#}$ & $0.96 \pm$ & $1.203 \pm 0.08^{* *}$ & $0.767 \pm$ & $1.703 \pm$ & $0.61=$ \\
\hline Bax & $1.19 \pm 0.137^{* \#}$ & $1.213 \pm 0.24^{* *}$ & $0.91 \pm 0.036^{\#}$ & $1.103 \pm 0.139^{* \#}$ & $1.223 \pm 0.315^{* \#}$ & $1.023 \pm 0.120^{* \#}$ & $0.53 \pm 0.07^{\sharp}$ & $0.943 \pm 0.176^{*}$ \\
\hline Caspase-3 & $0.31 \pm 0.233^{* \#}$ & $0.947 \pm 0.102^{* \#}$ & $1.18 \pm 0.092^{\# \#}$ & $1.137 \pm 0.095^{* \#}$ & $1.273 \pm 0.023^{* \#}$ & $1.277 \pm 0.033^{* \#}$ & $0.773 \pm 0.15^{\#}$ & $3.35 \pm 0.304^{*}$ \\
\hline Caspase-9 & $0.293 \pm 0.061^{* *}$ & $1.777 \pm 0.958^{* \#}$ & $0.663 \pm 0.087^{* \#}$ & $2.617 \pm 0.015^{* \#}$ & $0.747 \pm 0.012^{\# \#}$ & $2.580 \pm 0.469^{* \#}$ & $0.93 \pm 0.06^{\#}$ & $6.797 \pm 0.918^{\#}$ \\
\hline
\end{tabular}

$* \mathrm{P}<0.05$ vs normal (blank control group); $\# \mathrm{P}<0.05$ vs injury (injury control group).

$\mathrm{N}=6$ per group; Data presented as mean \pm standard deviation. 
a)

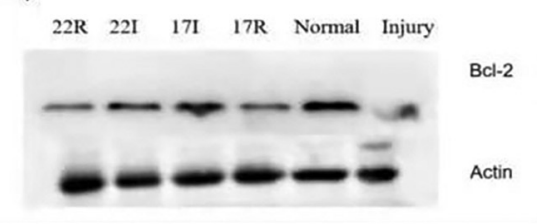

c)

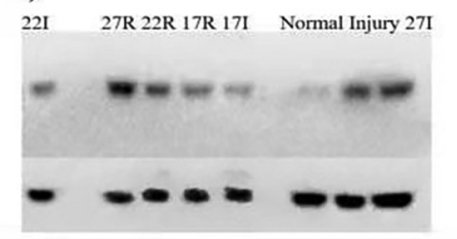

e)

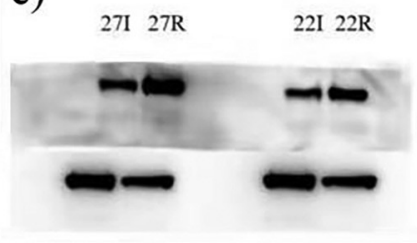

b)

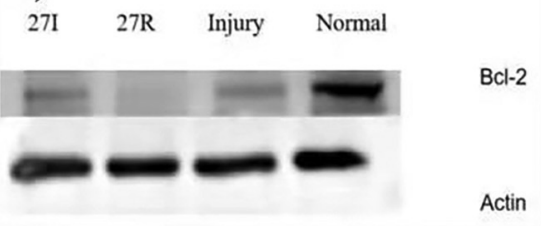

d)

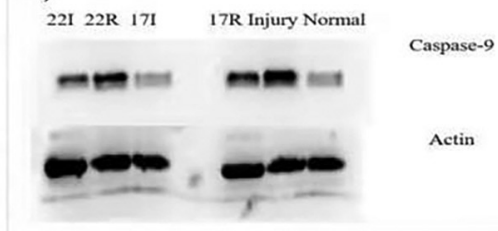

f)

$27 I \quad 27 R$ 22I 22R Injury Normal

g)

22I 17R 17I

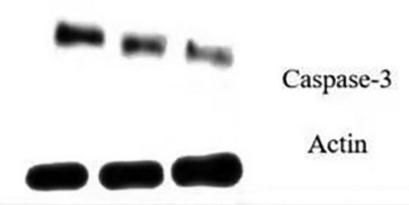

Figure 3 - Western blots showing the protein expressions of Bax, Bcl-2, Caspase-3, and Caspase-9 - Beijing, China, 2020.

compared with other temperature intervention groups. Figure 3 shows the protein expressions in each group.

\section{DISCUSSION}

Pressure Injury is a major health concern and the pathogenetic mechanism of $\mathrm{PI}$ is a contemporary research hotspot. In our study, we found increased expressions of Caspase-3, Bax, and Caspase- 9 in the muscle tissue in the injury control group compared with normal muscle. These elevated expression levels indicated activation of mitochondria-mediated apoptosis in I/R injury, which induced mitochondria dyshomeostasis.

We found that the muscle tissue of rats in the temperature intervention groups generally showed less damage, and the concentrations of apoptosis factors were significantly lower compared with those in the injury control group. Low temperature inhibited the upregulation of $\mathrm{Bax}$, and this resulted in the inhibition of downstream components - Caspase-3 and Caspase-9. These findings indicated that local intervention with low temperature during the development of stress injury can effectively reduce its occurrence.

Pressure Injury is mostly caused by I/R injury, and longterm ischemia leads to cell hypoxia ${ }^{(2,19)}$. Previous studies have found local increase in skin temperature during the development of PI, which may increase oxygen consumption and aggravate cell death ${ }^{(20-21)}$. In this study, low-temperature intervention during the formation reduced the expressions of apoptosis factors. This phenomenon was likely attributable to reduced cell metabolism and oxygen consumption, which interfered with cell death process and apoptosis, eventually reducing tissue damage.

In our study, we found that the expressions of mitochondria-mediated apoptosis factors were quite different in the temperature intervention groups. The 17I group showed the mildest tissue damage and the expressions of apoptosis factors in the $17 \mathrm{I}$ and $17 \mathrm{R}$ groups were lower than those in the other temperature intervention groups. The results showed that the temperature intervention of $16-18^{\circ} \mathrm{C}$ had the most significant impact on PI. This was the optimal temperature range that affected the occurrence and development of PI.

The expressions of mitochondria-mediated apoptosis factors were lower in 17I group compared with 17R group. Recent studies have shown that the changes in blood flow during the formation of PI may cause accumulation of inflammatory factors and increased consumption of oxygen, leading to tissue damage ${ }^{(22-23)}$. Low-temperature intervention during the ischemia period can reduce cell metabolism and tissue oxygen consumption, which inhibits the activation of apoptosis factors and upregulates the expression of anti-apoptotic factors during the formation of PI, leading to less cell death. Our results showed that ischemia period was 
the best time frame for $16-18^{\circ} \mathrm{C}$ temperature intervention to inhibit the development of PI.

\section{CONCLUSION}

In this study, temperature intervention of $16-18^{\circ} \mathrm{C}$ reduced the occurrence of apoptosis in muscle tissue.
Interventions to reduce local temperature to $16-18^{\circ} \mathrm{C}$ during the ischemia period can reduce the expressions of apoptosis factors and alleviate development of PI with I/R-mediated tissue damage. Our study may help inform new intervention methods for preventing PI in clinical nursing work and clarify the optimal temperature range for intervention.

\section{RESUMO}

Objetivo: Nosso objetivo foi determinar o efeito de diferentes intervenções na faixa de baixa temperatura em diferentes pontos do tempo em um modelo de lesão por pressão (IP) de rato produzida por lesão de isquemia/reperfusão (I / R). Métodos: Ratos SpragueDawley foram aleatoriamente designados para grupos de controle em branco, controle de lesão e intervenção por temperatura. Ratos nos grupos de controle de lesão e intervenção de temperatura (envolvendo exposição a diferentes faixas de temperatura em diferentes momentos) foram submetidos a três ciclos de lesão de I/R com isquemia de $2 \mathrm{~h}$ e reperfusão de $0,5 \mathrm{~h}$ para induzir IP. Resultados: Os tecidos musculares exibiram alterações degenerativas após a compressão. A intervenção em baixa temperatura de $16-18^{\circ} \mathrm{C}$ no período de isquemia resultou no menor grau de dano ao tecido e diminuiu significativamente os níveis de proteína $\mathrm{X}$ associada a Bcl-2 (Bax), caspase-9 e caspase-3. Além disso, resultou no nível de expressão mais alto de linfoma de células B 2 (Bcl-2) e níveis de expressão mais baixos de Bax, caspase- 9 e caspase-3 em tecidos musculares entre todos os grupos de intervenção. Conclusão: A intervenção em baixa temperatura de $16-18^{\circ} \mathrm{C}$ durante o período de isquemia mostrou efeitos ótimos nas expressões de fatores apoptóticos durante o desenvolvimento de IP com dano tecidual induzido por I/R.

\section{DESCRITORES}

Lesão por Pressão, Apoptose; Temperatura; Isquemia; Reperfusão; Mitocôndrias.

\section{RESUMEN}

Objetivo: Nuestro objetivo fue determinar el efecto de diferentes intervenciones de rango de temperatura baja en diferentes puntos de tiempo en un modelo de rata de lesión por presión (IP) producida por lesión por isquemia/reperfusión (I/R). Métodos: Se asignaron aleatoriamente ratas Sprague-Dawley a grupos de control en blanco, control de lesiones e intervención de temperatura. Las ratas en los grupos de control de lesiones e intervención de temperatura (que implican exposición a diferentes rangos de temperatura en diferentes puntos de tiempo) se sometieron a tres ciclos de lesión I/R con isquemia de $2 \mathrm{~h}$ y reperfusión de $0,5 \mathrm{~h}$ para inducir IP. Resultados: Los tejidos musculares presentaron cambios degenerativos después de la compresión. La intervención a baja temperatura de $16-18^{\circ} \mathrm{C}$ en el período de isquemia resultó en el grado más bajo de daño tisular y niveles significativamente reducidos de proteína $\mathrm{X}$ asociada a Bcl-2 (Bax), caspasa-9 y caspasa-3. Además, dio como resultado el nivel de expresión más alto de linfoma de células B 2 (Bcl-2) y los niveles de expresión más bajos de Bax, caspasa-9 y caspasa-3 en los tejidos musculares entre todos los grupos de intervención. Conclusión: La intervención a baja temperatura a $16-18^{\circ} \mathrm{C}$ durante el período de isquemia mostró efectos óptimos sobre la expresión de factores apoptóticos durante el desarrollo de IP con daño tisular inducido por I/R.

\section{DESCRIPTORS}

Úlcera por Presión, Apoptosis; Temperatura; Isquemia; Reperfusión; Mitocondrias.

\section{REFERENCES}

1. Mitchell A. Adult pressure area care: preventing pressure ulcers. Br J Nurs. 2018;27(18):1050-1052.

2. Razmus I, Bergquist-Beringer S. Pressure Injury Prevalence and the Rate of Hospital Acquired Pressure Injury Among Pediatric Patients in Acute Care. J Wound Ostomy Continence Nurs. 2017;44(2):110-7.

3. Bereded DT, Salih MH, Abebe AE. Prevalence and risk factors of pressure ulcer in hospitalized adult patients; a single center study from Ethiopia. BMC Research Notes. 2018;11(1): 847.

4. Wang Q, Zhu L, Xing F, Zhao P, Wang F. The comparison of the effects of local cooling and heating on apoptosis and pyroptosis of earlystage pressure ulcers in rats. J Cell Biochem. 2020;121(2):1649-1663.

5. Ruh AC, Frigo L, Cavalcanti MFXB, Svidnicki P, Vicari VN, Lopes-Martins RAB, et al. Laser photobiomodulation in pressure ulcer healing of human diabetic patients: gene expression analysis of inflammatory biochemical markers. Lasers Med Sci. 2018;33(1):165-171.

6. Ugwu FN, Yu AP, Sin TK, Tam BT, Lai CW, Wong SC, et al. Protective Effect of Unacylated Ghrelin on Compression-Induced Skeletal Muscle Injury Mediated by SIRT1-Signaling.Front Physiol. 2017;8:962.

7. Zeevi T, Levy A, Brauner N, Gefen A. Effects of ambient conditions on the risk of pressure injuries in bedridden patients-multi-physics modelling of microclimate. Int Wound J. 2018;15(3): 402-416.

8. Choi DE, Jeong JY, Choi H, Chang YK, Ahn MS, Ham YR, et al. ERK phosphorylation plays an important role in the protection afforded by hypothermia against renalischemia-reperfusion injury. Surgery. 2017;161(2):444-452.

9. Yang M, Antoine DJ, Weemhoff JL, Jenkins RE, Farhood A, Park BK, et al. Biomarkers distinguish apoptotic and necrotic cell death during hepaticischemia/ reperfusion injury in mice. Liver Transpl. 2014;20(11):1372-82.

10. Yao Y, Da Ong LX, Li X, Wan K, Mak AF. Effects of Biowastes Released by Mechanically Damaged Muscle Cells on the Propagation of Deep Tissue Injury: A Multiphysics Study. Ann Biomed Eng. 2017;45(3):761-774.

11. Cui FF, Pan YY, Xie HH, Wang XH, Shi HX, Xiao J, et al. Pressure Combined withischemia/Reperfusion Injury Induces Deep Tissue Injury via Endoplasmic Reticulum Stress in a Rat Pressure Ulcer Model. Int J Mol Sci. 2016;17(3):284.

12. Zhu S, Chen M, Chen M, Ye J, Ying Y, Wu Q, et al. Fibroblast Growth Factor 22 Inhibits ER Stress-Induced Apoptosis and Improves Recovery of Spinal Cord Injury. Front Pharmacol. 2020;11:18. 
13. Wang Y, Pu L, Li Z, Hu X, Jiang L. Hypoxia-inducible factor-1a gene expression and apoptosis inischemia-reperfusion injury a rat model of early-stage pressure ulcer. Nurs. Res. 2016;65(1):35-46.

14. Jiménez-Castro MB, Cornide-Petronio ME, Gracia-Sancho J, Peralta C. Inflammasome-Mediated Inflammation in Liverischemia-Reperfusion Injury.Cells. 2019;8(10):1131.

15. Guohong Ye, Qiang Fu, Luping Jiang, Zhiliang Li. Vascular smooth muscle cells activate PI3K/Akt pathway to attenuate myocardialischemia/ reperfusion-induced apoptosis and autophagy by secreting bFGF.Biomed Pharmacother. 2018;107:1779-1785.

16. Rocca C, Boukhzar L, Granieri MC, Alsharif I, Mazza R, et al. A selenoprotein T-derived peptide protects the heart againstwaschaemia/ reperfusion injury through inhibition of apoptosis and oxidative stress.Acta Physiol (Oxf). 2018;223(4):e13067. DOI: https://doi. org/10.1111/apha.13067.

17. Lin A, Shih CT, Huang CL, Wu CC, Lin CT, Tsai YC. Hypnotic Effects of Lactobacillus fermentum PS150 TM on Pentobarbital-Induced Sleep in Mice. Nutrients. 2019;11(10):2409. DOI: https://doi.org/10.3390/nu11102409.

18. Druda DF, Gone S, Graudins A. Deliberate Self-poisoning with a Lethal Dose of Pentobarbital with Confirmatory Serum Drug Concentrations: Survival After Cardiac Arrest with Supportive Care. J Med Toxicol. 2019;15(1):45-48.

19. Spruce L. Back to Basics: Preventing Perioperative Pressure Injuries. AORN J. 2017;105(1):92-99.

20. Chen J, Zhang DM, Feng X, Wang J, Qin YY, Zhang T, et al. TIGAR inhibitsischemia/reperfusion-induced inflammatory response of astrocytes. Neuropharmacology. 2018;131:377-388.

21. Jiménez-Castro MB, Cornide-Petronio ME, Gracia-Sancho J, Peralta C. Inflammasome-Mediated Inflammation in Liverischemia-Reperfusion Injury. Cells. 2019;8(10):1131.

22. Skrzek A, Ciszek A, Nowicka D, Dębiec-Bąk A. Evaluation of changes in selected skin parameters under the influence of extremely low temperature. Cryobiology. 2019;86:19-24.

23. Jan YK. The effects of local cooling rates on perfusion of sacral skin under externally applied pressure in people with spinal cord injury: an exploratory study. Spinal Cord. 2020;58(4):476-483. 